\title{
Article \\ Germination Parameters of Selected Summer Weeds: Transferring of the AlertInf Model to Other Geographical Regions
}

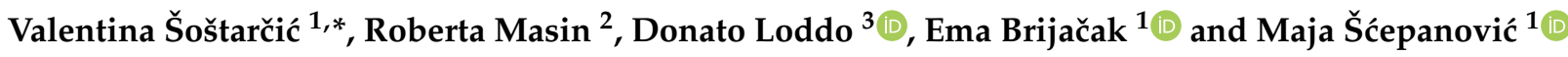 \\ 1 Department of Weed Sciences, Faculty of Agriculture, University of Zagreb, Svetošimunska 25, \\ 10000 Zagreb, Croatia; ebrijacak@agr.hr (E.B.); mscepanovic@agr.hr (M.Š.) \\ 2 Department of Agronomy, Food, Natural Resources, Animals and Environment (DAFNAE), \\ University of Padova, Viale dell' Università 16, 35020 Legnaro, Italy; roberta.masin@unipd.it \\ 3 Institute for Sustainable Plant Protection, National Research Council of Italy, Viale dell'Università 16, \\ 35020 Legnaro, Italy; donato.loddo@cnr.it \\ * Correspondence: vsostarcic@agr.hr
}

Citation: Šoštarčić, V.; Masin, R.; Loddo, D.; Brijačak, E.; Šćepanović, M. Germination Parameters of Selected Summer Weeds: Transferring of the AlertInf Model to Other Geographical Regions. Agronomy 2021, 11, 292. https://doi.org/10.3390/agronomy 11020292

Academic Editor: Aritz Royo-Esnal Received: 23 December 2020

Accepted: 2 February 2021

Published: 5 February 2021

Publisher's Note: MDPI stays neutral with regard to jurisdictional claims in published maps and institutional affiliations.

Copyright: () 2021 by the authors. Licensee MDPI, Basel, Switzerland. This article is an open access article distributed under the terms and conditions of the Creative Commons Attribution (CC BY) license (https:// creativecommons.org/licenses/by/ $4.0 /)$.

\begin{abstract}
Effective weed management depends on correct control timing, which depends on seedling emergence dynamics. Since soil temperature and soil moisture are the two main factors that determine weed germination, the hydrothermal time model can be used to predict their emergence. The aim of this study was to estimate the base temperature $\left(T_{b}\right)$ and base water potential $\left(\Psi_{b}\right)$ for the germination of Chenopodium album, Amaranthus retroflexus, Setaria pumila, and Panicum capillare collected from fields in continental Croatia and then to compare these values with those of Italian populations embedded in the AlertInf model. Germination tests were performed at seven constant temperatures (ranging from 4 to $27^{\circ} \mathrm{C}$ ) and eight water potentials $(0.00-1.00 \mathrm{MPa})$. The estimated $\mathrm{T}_{\mathrm{b}}$ and $\Psi_{\mathrm{b}}$ were $3.4{ }^{\circ} \mathrm{C}$ and $-1.38 \mathrm{MPa}$ for $\mathrm{C}$. album, $13.9^{\circ} \mathrm{C}$ and $-0.36 \mathrm{MPa}$ for A. retroflexus, $6.6^{\circ} \mathrm{C}$ and $-0.71 \mathrm{MPa}$ for S. pumila, and $11.0^{\circ} \mathrm{C}$ and $-0.87 \mathrm{MPa}$ for P. capillare, respectively. According to the criterion of overlap of the $95 \%$ confidence intervals, only the $T_{b}$ of $C$. album and the $\Psi_{b}$ of A. retroflexus of the Croatian and Italian populations were similar. Further field experiments should be conducted to monitor the weed emergence patterns of $C$. album and calibrate the AlerInf equation parameters.
\end{abstract}

Keywords: base temperature; base water potential; maize; predictive weed emergence model; weed germination

\section{Introduction}

Integrated Weed Management (IWM) recommends the use of different weed control methods with the main objective of developing crop production systems that require less herbicide use. To achieve this goal and maximize herbicide efficacy, herbicide mixtures should be closely matched to the specific botanical composition of the weed flora in the field. Achieving an effective control is highly dependent on the timing of the herbicide application, which depends on the weed emergence dynamics [1]. Therefore, knowledge of the timing and duration of weed emergence could facilitate the achievement of effective herbicide application, without subsequent corrective treatments [2]. In addition, compared to standard management practice, it allows for lower herbicide application and lower weed control costs [3]. Weed emergence data constitute a basis for the development of predictive weed emergence models. These models provide the percentage of cumulative weed emergence achieved daily in the field, with the aim of suggesting the best time for farmers to control weeds [1]. Several predictive weed emergence models have been developed and are currently available for growers of maize [4,5], soybeans [2,6], and winter cereals $[7,8]$ in Europe and the United States. These models are often based on the concept of thermal time (TT) or hydrothermal time (HTT) [9], depending on whether they consider only temperature (TT) or temperature and soil moisture (HTT) as triggers for germination. 
HTT models start calculating hydrothermal units when the soil temperature and water potential reach the value of the estimated base temperature $\left(\mathrm{T}_{\mathrm{b}}\right)$ and base water potential $\left(\Psi_{b}\right)$ for the germination of certain weed species. The prediction of HTT models is usually more accurate, as they are able to predict the pauses in seedling emergence caused by a low soil water potential $[1,3,10]$, which could not be predicted by TT models. The calculation of HT requires the estimation of germination parameters, which are the base temperature $\left(T_{b}\right)$ and base water potential $\left(\Psi_{b}\right)$, to simulate the seedling emergence according to the weather trends [11].

In Croatia, maize is the most important annual crop, averaging 260,000 hectares per year, which corresponds to about $32 \%$ of the country's arable land [12]. Maize is almost always cultivated without irrigation, and weed control relies mainly on postemergence herbicides. The prediction of weed emergence is therefore very important for the identication of the correct timing for herbicide application. Currently, there are no developed models; therefore, the transfer of the existing model from geographically close areas $[4,11]$ would greatly benefit maize growers.

The criteria for the transfer of a HTT model developed in another area are the presence of the main weed species in the existing model and overlap between the values of the germination parameters of the domestic and foreign populations built into the model. In case of overlapping values, the existing model can be validated in a maize field, without repeated monitoring of weed emergence dynamics over many years.

The inter-population variability of weed species may limit the transferability of the HTT model, as it has been reported that local populations may develop different germination behavior in adapting to local environmental conditions [11,13]. For example, differences between the $\mathrm{T}_{\mathrm{b}}$ values in the Italian and Portuguese populations of Datura stramonium L. [13], the American and European populations of A. artemisiifolia L. [14], and the German and French populations of Chenopodium album L. and Echinochloa crus-galli (L.) P. Beauv [15] have been reported. In contrast, similar $\mathrm{T}_{\mathrm{b}}$ values were found for Amaranthus retroflexus L., Abutilon theophrasti Med., and Chenopodium album L. between populations from different regions of Italy, Veneto, and Tuscany [1]. Thus, in transfering a model to geographical areas other than that in which it was created, the behavior of the local population should be tested [11].

Of the HTT models developed so far, the one geographically closest to the continental part of Croatia is the AlertInf model, developed in Italy (Veneto) for predicting the emergence of ten weed species: A. theophrasti, Digitaria sanguinalis (L.) Scop., E. crus-galli, Polygonum persicaria L., Setaria pumila (L.) P. Beauv, Setaria viridis (L.) Beauv., Solanum nigrum L., A. retroflexus, C. album, and Sorghum halepense (L.) Pers. [1,4].

Previous studies found no statistical difference between the germination parameters adopted for the Italian population of $A$. theophrasti included in the AlertInf model and the values estimated using the same methodology for a Croatian population [16]. The results of these preliminary studies indicate the possibility of transferring AlertInf to other geographical regions (Croatia), but further studies are needed to include other thermophilic weed species that are common in maize fields in Croatia. Hence, the aim of this research was to estimate the $\mathrm{T}_{\mathrm{b}}$ and $\Psi_{\mathrm{b}}$ for four weed species: A. retroflexus, C. album, S. pumila, and Panicum capillare L. collected from fields in continental Croatia and then to compare these values with the values of the Italian populations embedded in the AlertInf model in order to verify the possibility of using the predicative weed emergence model in geographically and climatologically different areas.

\section{Materials and Methods}

\subsection{Site Description and Comparison}

In order to verify the transferability of the AlertInf model from one geographical location to another that is climatologically different, the values of the germination parameters of seeds collected from Croatia (Zagreb) and Italy (Padova) were compared. According to the Köppen-Geiger climate classification [17], Zagreb is classified as Dfb, with a cold 
climate, precipitation without a dry season, and a warm summer. Padova is classified as Cfa, with a temperate climate, precipitation without a dry season, and a warm summer. For Padova, the average annual temperatures and precipitation were taken from Masin et al. [6], and for Zagreb, they were taken from the Croatian Meteorological and Hydrological Service. The average annual precipitation in Zagreb is $861.1 \mathrm{~mm}$, with the minimum precipitation in February $(44.6 \mathrm{~mm})$ and maximum in September $(101.6 \mathrm{~mm})$. The average annual temperature is $11.8^{\circ} \mathrm{C}$, with the minimum temperature in January $\left(-3.2^{\circ} \mathrm{C}\right)$ and maximum in August $\left(25.0^{\circ} \mathrm{C}\right)$. Padova has an average annual precipitation of about $850 \mathrm{~mm}$, which is uniformly distributed throughout the year. The average annual temperature is $12.2^{\circ} \mathrm{C}$, with temperature increases from January (average minimum value: $-1.5^{\circ} \mathrm{C}$ ) to July (average maximum value: $27.2^{\circ} \mathrm{C}$ ).

\subsection{Seed Material}

The seeds of S. pumila, P. capillare, A. retroflexus, and C. album were hand-picked from plants in maize fields at physiological maturity. The seeds of C. album and S. pumila were collected at the Experimental Station of the University of Zagreb Faculty of Agriculture, Sasinovecki Lug $\left(45^{\circ} 50^{\prime} 59.6^{\prime \prime} \mathrm{N} ; 16^{\circ} 09^{\prime} 53.9^{\prime \prime} \mathrm{E}\right)$, the seeds of $A$. retroflexus were collected at the Experimental Station Maksimir $\left(45^{\circ} 49^{\prime} 34.3^{\prime \prime} \mathrm{N} ; 16^{\circ} 01^{\prime} 49.8^{\prime \prime} \mathrm{E}\right)$, and the seeds of P. capillare were collected at the site, Lipovec Lonjski $\left(45^{\circ} 44^{\prime} 51.9^{\prime \prime} \mathrm{N} ; 16^{\circ} 23^{\prime} 12.4^{\prime \prime} \mathrm{E}\right)$. The collected seeds were brought to the laboratory and cleaned, sieved, and stored in paper bags in the refrigerator $\left(4^{\circ} \mathrm{C}\right)$ until the beginning of the experiment.

\subsection{Germination Experiments}

Experiments to estimate base temperature and base water potential for germination were conducted at the University of Padova, Department of Agronomy, Food, Natural Resources, Animals, and Environment, and the University of Zagreb, Faculty of Agriculture, Department of Weed Science, from 2013 to 2020. Prior to the start of the experiments, a preliminary germination test in a climate chamber (W87R, KW Apparecchi Scientifici SRL, via della Resistenza 119, 53035 Monteriggioni, Italy) at a constant temperature $\left(25^{\circ} \mathrm{C}\right)$ and photoperiod of $12 \mathrm{~h} / 12 \mathrm{~h}$ (day/night) was conducted to check the germination capacity of the seeds. Seed populations that achieved a germination higher than $60 \%$ were included in further studies.

The estimation of the base temperature of the four weed species was performed by simultaneously testing the germination at six or seven constant temperatures, with a photoperiod of $12 \mathrm{~h} / 12 \mathrm{~h}$ (day/night) in different climatic chambers. The seeds were calibrated and uniformed before placing them on filter paper. To prevent the growth of pathogens on the seeds and on the filter paper, the seeds were sterilized with $1 \%$ hydrogen peroxide and washed with distilled water. According to the amount of uniformed seed, three replicates of 100 seeds of C. album, A. retroflexus, and P. capillare and five replicates of 50 seeds of $S$. pumila were placed in a Petri dish on Whatman ${ }^{\circledR}$ filter paper. The filter paper was covered with $5 \mathrm{~mL}$ of distilled water, and the Petri dishes were sealed with parafilm. The initial temperature was defined for each weed species as one degree lower than the base temperature previously established in the literature $[11,18-20]$. Therefore, $C$. album and $S$. pumila were tested at a constant temperature of $4,8,12,16,20,24$, and $28^{\circ} \mathrm{C}$. Furthermore, the germination of $A$. retroflexus was tested at $9,12,15,18,21,24$, and $27^{\circ} \mathrm{C}$, and that of $P$. capillare was tested at $6,9,12,15,18,21,24,27$, and $30{ }^{\circ} \mathrm{C}$.

To estimate the base water potential of each species, a germination test was carried out, exposing the seeds to different levels of water potential, that is, different levels of water availability. As described before, three replicates per 100 seeds or five replicates per 50 seeds were placed in eight different water potential solutions. For this purpose, polyethylene glycol (PEG) 6000 (Sigma-Aldrich Chemie GmbH 25322-68-3, St. Louis, MO, USA) was used to prepare the solutions with eight water stress levels: 0.00 (pure distilled water), $-0.05,-0.10,-0.25,-0.38,-0.50,-0.80$, and $-1.00 \mathrm{MPa}$, according to Michel and Kaufmann [21]. The seeds were placed in transparent plastic containers with diameter and 
height of $10 \mathrm{~cm}$ and $7 \mathrm{~cm}$, respectively, as described by Masin et al. [1]. Containers with $50 \mathrm{~mL}$ of the prepared solution were placed at a constant temperature of $22{ }^{\circ} \mathrm{C}$, with a photoperiod of $12 \mathrm{~h} / 12 \mathrm{~h}$ (day/night).

In both germination experiments, the seeds were defined as germinated when the seed radicle was $1 \mathrm{~mm}$ long. Germinated seeds incubated at the temperatures above $20^{\circ} \mathrm{C}$ and with all water potentials above $-0.38 \mathrm{MPa}$ were counted and removed twice daily, and germinated seeds incubated at temperatures below $20^{\circ} \mathrm{C}$ and with water potentials below $-0.38 \mathrm{MPa}$ were counted and removed once. The germination test was considered complete when no germination was detected for 10 consecutive days. The germination test lasted between 9 and 95 days, depending on the temperature or water potential and tested weed species.

The temperature in the climate chambers was recorded hourly using temperature data loggers (HOBO UA-001-08, Onset Computer Corporation, Bourne, MA, USA). Temperature deviations $\pm 0.5^{\circ} \mathrm{C}$ were considered acceptable.

\subsection{Statistical Analysis and Statistical Methods}

The effect of temperature and water potential on final germination percentages was evaluated with regression analysis. A parabolic model was used to describe the effect of temperature, as follows:

$$
\mathrm{FG}=\mathrm{aT}^{2}+\mathrm{bT}+\mathrm{c}
$$

where, FG is the percentage of final germination, $\mathrm{T}$ is the temperature expressed in ${ }^{\circ} \mathrm{C}$, and $a, b$, and $c$ are constant numbers with a not equal to zero.

An exponential model was used to describe the effect of water potential, as follows:

$$
\mathrm{FG}=\mathrm{FG}_{0} \cdot \exp (-\mathrm{k} \Psi)
$$

where, $\mathrm{FG}$ is the percentage of final germination, $\mathrm{FG}_{0}$ is the highest percentage when the water potential of the solution is equal to zero, $\Psi$ is the water potential expresses in $\mathrm{MPa}$, and $\mathrm{k}$ is rate constant.

The germination dynamics curve was generated using the logistic function in the Bioassay97 statistical program [22] to determine the initial $\left(t_{10}\right)$, medium $\left(t_{50}\right)$, and final $\left(t_{90}\right)$ germination time with the formula:

$$
C G=100 / 1+\exp \{a[\ln (t+0.0000001)-\ln (b)]\}
$$

where, $C G$ is the percentage of cumulative germination, $t$ is the time expressed in days, $a$ is the slope of the curve, and $b$ is the inflection point. The initial $\left(t_{10}\right)$, medium $\left(t_{50}\right)$, and final $\left(t_{90}\right)$ germination time, i.e., the time it takes for $10 \%, 50 \%$, and $90 \%$ of the germinating seeds to germinate, are determined by the slope of the curve (b). The effect of the temperature and water potential on germination dynamics, expressed in days (that is on $t_{10}, t_{50}$, and $t_{90}$ ), was analyzed by means of variance analysis (ANOVA). After the significant F-test, the LSD test for $p=0.05$ was used to compare the mean values.

The germination parameters were determined using germination dynamics data at different temperatures and water potentials for each species studied. The reciprocal of $t_{50}$ $\left(1 / t_{50}\right)$ was used to establish the linear regression line against the incubation temperature or water potential [1]. The values of $T_{b}$ and $\Psi_{b}$ were presented as the point where the linear regression line intersects the abscissa. The $95 \%$ confidence intervals for $\mathrm{T}_{\mathrm{b}}$ and $\Psi_{\mathrm{b}}$ were determined using the bootstrap method [23]. The values obtained for the germination parameters of the Croatian populations were compared with the values of the Italian built into the AlertInf model, according to the criterion of overlap of the $95 \%$ confidence intervals [1]. If there is no overlapping of the confidence intervals between the two populations, a significant difference is determined. 


\section{Results}

\subsection{Weeds Germination at Different Temperatures and Water Potentials}

Regression analysis showed very different influence of temperature and water potential on germination of the studied species (Figures 1 and 2).

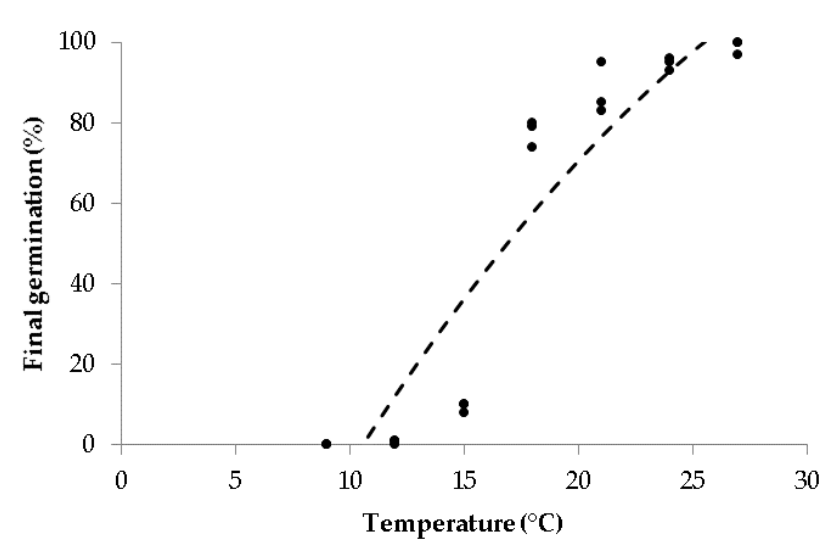

(a)

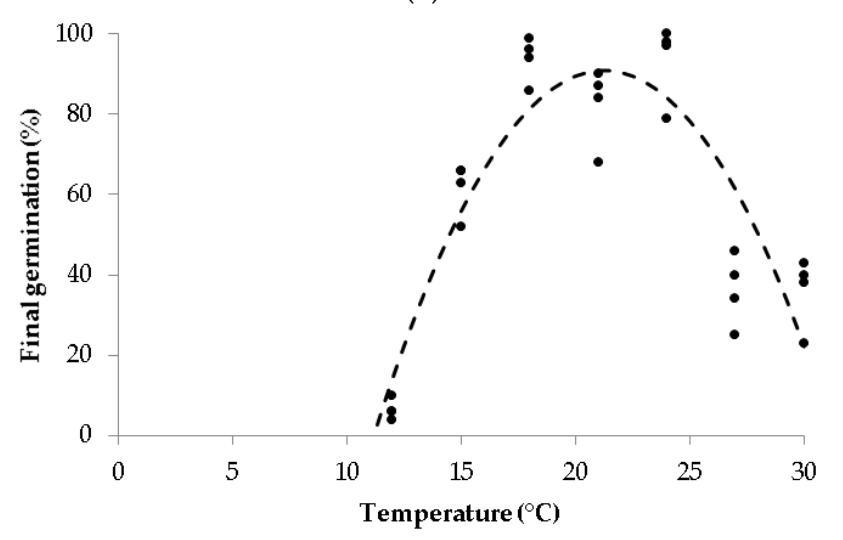

(c)

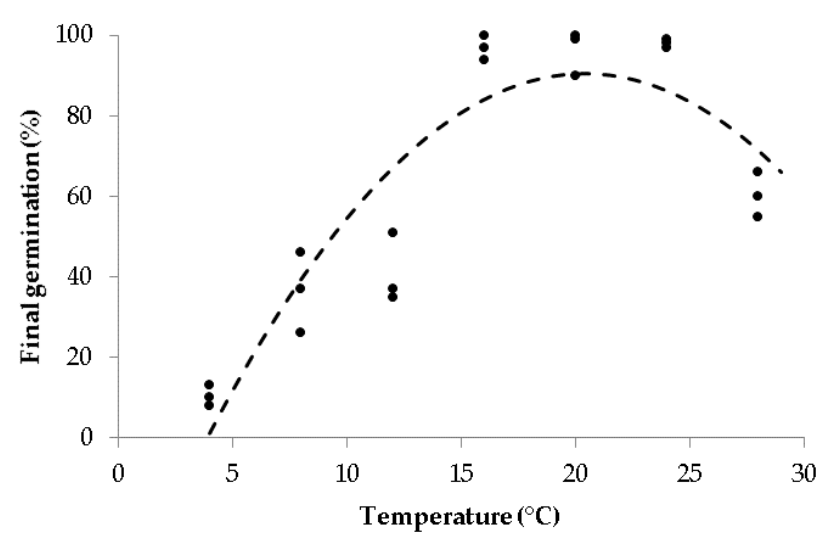

(b)

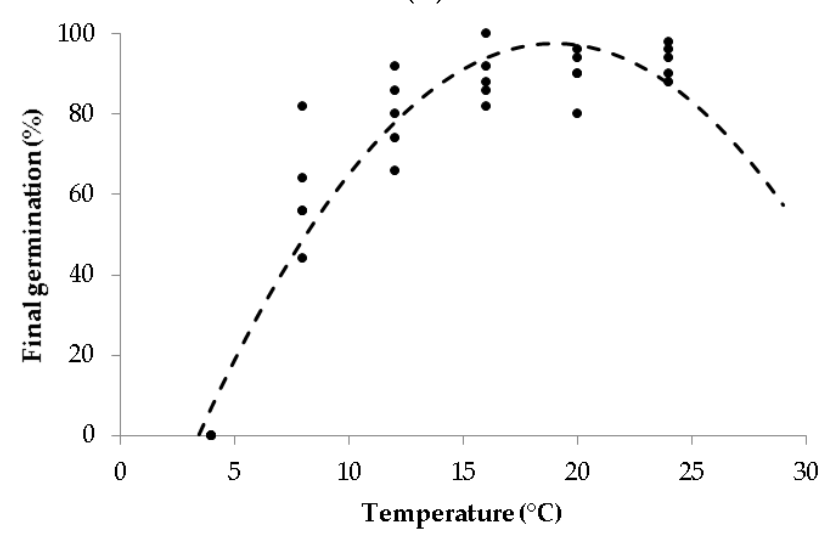

(d)

Figure 1. Final germination (\%) of A. retroflexus, C. album, P. capillare, and S. pumila at studied temperatures. The dotted line represents the regression line and the points the observed final germination percentages. Estimated function are: (a) Amaranthus retroflexus $\mathrm{y}=-0.1 \mathrm{x}^{2}+11.8 \mathrm{x}-108.6, r^{2}=0.87$; (b) Chenopodium album $\mathrm{y}=-0.3 \mathrm{x}^{2}+13.6 \mathrm{x}-48.0, r^{2}=0.82$;

(c) Panicum capillare $\mathrm{y}=-0.9 \mathrm{x}^{2}+38.1-314.1, r^{2}=0.78$; (d) Setaria pumila $\mathrm{y}=-0.4 \mathrm{x}^{2}+15.3 \mathrm{x}-47.9, r^{2}=0.91$.

The germination of the studied species varied between $0.67 \%$ and $99 \%$, depending on the incubation temperature or weed species (Figure 1). Among the tested weed species, C. album showed the ability to germinate at the lowest temperature $\left(4^{\circ} \mathrm{C}\right)$, while the other species started to germinate at $8^{\circ} \mathrm{C}($ S. pumila $)$ or $12{ }^{\circ} \mathrm{C}($ A. retroflexus and $P$. capillare). The highest germination percentage of all four species was reached at $24{ }^{\circ} \mathrm{C}$ : C. album (98\%), A. retroflexus (95\%), S. pumila (93\%), and P. capillare (93\%). However, A. retroflexus also achieved a similar germination percentage at $27^{\circ} \mathrm{C}$, and C. album and S. pumila achieved this percentage within a temperature range of $16-24^{\circ} \mathrm{C}$. Germination began to decrease as the temperature dropped, but this process was species-specific. These results indicate that incubation temperatures greatly affect the germination of the tested weed species.

Similarly, water potential greatly affected the germination of the weed species. For all tested weed species, germination began to decrease as the water potential dropped (Figure 2). The germination of $S$. pumila and $C$. album showed a slow reduction. A. retroflexus presented a fast decrease of germination with a strong inhibition from $-0.25 \mathrm{MPa}$. P. capillare germination decreased with an intermediate reduction rate compared to the other species. Almost all weed species presented very low or no germinated seeds at -0.80 and $-1.00 \mathrm{MPa}$, except C. album 
that showed germination also at $-1.00 \mathrm{MPa}$. Taken together, these findings demonstrate that the germination of all species decreased significantly at lower water potentials, but germination ability at different water potentials was also species-specific.

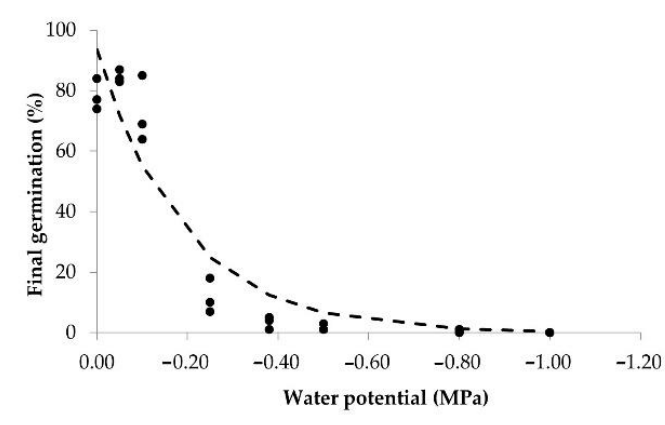

(a)

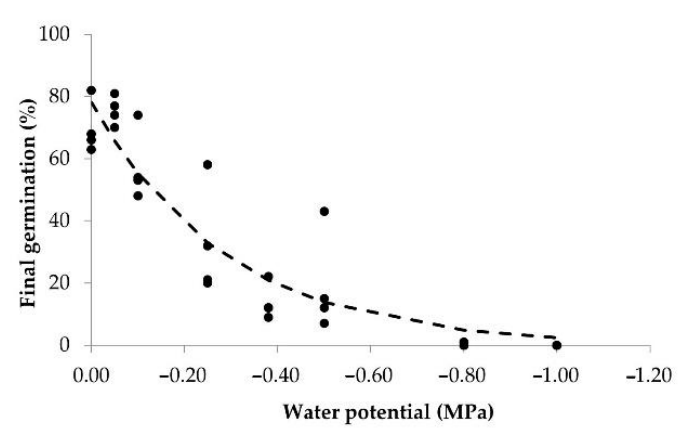

(c)

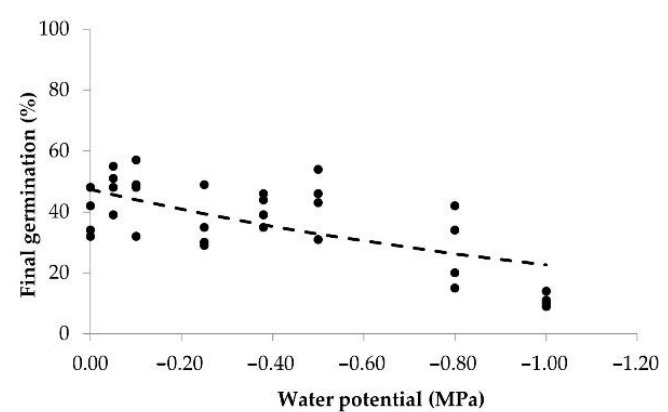

(b)

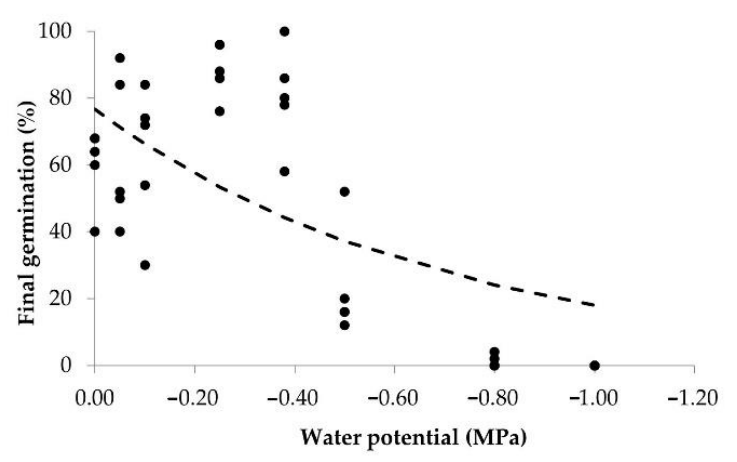

(d)

Figure 2. Final germination percentage of the studied weed species at different water potentials (MPa). The dotted line represents the regression line and the points the observed final germination percentages. Estimated functions are: (a) Amaranthus retroflexus $\mathrm{y}=93.5 \exp (-5.3 \mathrm{x}), r^{2}=0.90 ;(\mathbf{b})$ Chenopodium album y $=47.4 \exp (-0.7 \mathrm{x}) . r^{2}=0.45 ;$ (c) Panicum capillare $\mathrm{y}=78.1 \exp (-3.5 \mathrm{x}), r^{2}=0.87 ;(\mathbf{d})$ Setaria pumila $\mathrm{y}=76.7 \exp (-1.5 \mathrm{x}), r^{2}=0.46$.

\subsection{Germination Dynamics in Response to Different Temperatures and Estimation of Base Temperature}

Daily recorded germination data were used to obtain germination dynamic curves at each studied temperature. The germination dynamics were influenced by temperature in all tested species (Table 1). A decrease in temperature led to an increase in the number of days required for the start and end of germination for all species. The duration of germination varied between 0.6 and 76.0 days $(\mathrm{d})$, depending on the incubation temperature and the species studied. At $24{ }^{\circ} \mathrm{C}$, the initial germination $\left(t_{10}\right)$ was shortest for $A$. retroflexus $(1.0 \mathrm{~d})$ and longest for C. album ( $3.3 \mathrm{~d})$. At the same temperature, A. retroflexus needed $1.4 \mathrm{~d}$ to achieve medium germination $\left(\mathrm{t}_{50}\right)$, while $C$. album had a longer trend, and the longest $t_{50}$ value was 4.5 days. In contrast, no statistical difference was found between two monocotyledonous species, $P$. capillare and $S$. pumila, in the medium germination $\left(\mathrm{t}_{50}\right)$ at a temperature of $24{ }^{\circ} \mathrm{C}$. The end of germination ( $\left.\mathrm{t}_{90}\right)$ was reached for A. retroflexus in $1.8 \mathrm{~d}$, while C. album and P. capillare finished germination in 6.2 and $7.0 \mathrm{~d}$.

As expected, lower temperatures prolonged the germination of all investigated species. Due to the low germination capacity of $A$. retroflexus at $12{ }^{\circ} \mathrm{C}(0.67 \%)$, it was not possible to establish a germination curve for this species, unlike at other temperatures. The initial, medium, and final germination of the other three species at $12{ }^{\circ} \mathrm{C}$ varied between 5.83 and 24.38 d. C. album and S. pumila started germination at 5.83 and $8.98 \mathrm{~d}$, while P. capillare extended the start of germination to $12.17 \mathrm{~d}$. S. pumila was the species that reached, before the others, the end of germination ( $\mathrm{t}_{90}$ at $12.3 \mathrm{~d}$ ), while P. capillare set the end of germination to $24.38 \mathrm{~d}$. 
Table 1. Germination dynamics $\left(t_{10}, t_{50}\right.$, and $\left.t_{90}\right)$ at the different studied temperatures.

\begin{tabular}{|c|c|c|c|c|c|c|c|c|c|c|c|c|}
\hline \multirow{2}{*}{${ }^{\circ} \mathrm{C}$} & \multicolumn{3}{|c|}{ P. capillare } & \multicolumn{3}{|c|}{ C. album } & \multicolumn{3}{|c|}{ S. pumila } & \multicolumn{3}{|c|}{ A. retroflexus } \\
\hline & $t_{10}$ & $t_{50}$ & $\mathrm{t}_{90}$ & $\mathbf{t}_{10}$ & $t_{50}$ & $t_{90}$ & $t_{10}$ & $t_{50}$ & $t_{90}$ & $\mathbf{t}_{10}$ & $t_{50}$ & $t_{90}$ \\
\hline 4 & - & - & - & $31.2 \mathrm{c}$ & $48.3 \mathrm{~d}$ & $76.0 \mathrm{~d}$ & - & - & & - & - & - \\
\hline 8 & - & . & 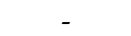 & $18.0 \mathrm{~b}$ & $33.9 \mathrm{c}$ & $63.9 c$ & $24.3 \mathrm{~d}$ & $28.0 \mathrm{~d}$ & $32.4 \mathrm{~d}$ & - & - & - \\
\hline 12 & 12.17 e B & $17.03 \mathrm{~d} \mathrm{~A}$ & $24.38 \mathrm{~d} \mathrm{C}$ & $5.8 \mathrm{a} \mathrm{A}$ & $9.7 \mathrm{~b} \mathrm{~A}$ & $16.4 \mathrm{~b} \mathrm{~B}$ & $8.8 \mathrm{c} \mathrm{AB}$ & $10.4 \mathrm{cB}$ & $12.3 \mathrm{c} \mathrm{A}$ & - & - & - \\
\hline 15 & $9.87 \mathrm{~d}$ & 11.34 c & $13.04 \mathrm{c}$ & - & & & - & & & $3.5 c$ & $5.7 \mathrm{e}$ & $9.5 \mathrm{~d}$ \\
\hline 16 & - & - & - & $4.1 \mathrm{a}$ & $6.6 \mathrm{ab}$ & $10.8 \mathrm{ab}$ & $5.0 \mathrm{~b}$ & $6.3 \mathrm{~b}$ & $8.1 \mathrm{~b}$ & - & - & - \\
\hline 18 & $3.46 \mathrm{bc}$ & $4.03 \mathrm{~b}$ & $4.70 \mathrm{ab}$ & - & - & & - & - & & $3.0 \mathrm{c}$ & $3.6 \mathrm{~d}$ & $4.2 \mathrm{c}$ \\
\hline 20 & - & - & - & $3.6 \mathrm{a}$ & $4.9 \mathrm{a}$ & $6.8 \mathrm{a}$ & $3.6 \mathrm{ab}$ & $4.8 \mathrm{ab}$ & $6.2 \mathrm{ab}$ & - & - & - \\
\hline 21 & $2.87 \mathrm{bc}$ & $3.80 \mathrm{~b}$ & $5.11 \mathrm{ab}$ & - & - & - & - & - & - & $1.7 \mathrm{~b}$ & $2.2 \mathrm{c}$ & $2.8 \mathrm{~b}$ \\
\hline 24 & $1.64 \mathrm{a}-\mathrm{c} B$ & $3.39 \mathrm{~b} \mathrm{~B}$ & 7.06 b C & 3.3 a D & 4.5 a C & 6.2 a C & $2.3 \mathrm{a} \mathrm{C}$ & 3.0 a B & 3.8 a B & $1.0 \mathrm{ab} \mathrm{A}$ & $1.4 \mathrm{~b} \mathrm{~A}$ & $1.8 \mathrm{ab} \mathrm{A}$ \\
\hline 27 & $1.48 \mathrm{ab}$ & $1.87 \mathrm{a}$ & $2.37 \mathrm{a}$ & - & - & - & - & - & - & $0.6 \mathrm{a}$ & $0.9 \mathrm{a}$ & $1.5 \mathrm{a}$ \\
\hline 28 & & & & $1.9 \mathrm{a}$ & $3.4 \mathrm{a}$ & $6.3 \mathrm{a}$ & - & - & - & - & - & - \\
\hline 30 & $0.75 \mathrm{a}$ & $1.89 \mathrm{a}$ & $6.28 \mathrm{~b}$ & - & - & - & - & - & - & - & - & - \\
\hline
\end{tabular}

Different small letters (a-e) within a column indicate a statistical difference in each parameter separately for one species according to Fisher's Least Significant Difference (LSD) test at $p<0.05$. Different capital letters (A-D) indicate a statistical difference between species in each parameter separately $\left(\mathrm{t}_{10}, \mathrm{t}_{50}\right.$, and $\left.\mathrm{t}_{90}\right)$ according to Fisher's Least Significant Difference (LSD) test at $p<0.05$.

A linear regression line was used to estimate the $\mathrm{T}_{\mathrm{b}}$ of the studied weed species (Figure 3). The highest $\mathrm{T}_{\mathrm{b}}$ value was estimated for $A$. retroflexus $\left(13.9 \pm 0.36^{\circ} \mathrm{C}\right)$ and the lowest was estimated for $C$. album $\left(3.4 \pm 0.36^{\circ} \mathrm{C}\right)$, while P. capillare and S. pumila presented intermediate values $\left(11.0 \pm 1.99^{\circ} \mathrm{C}\right.$ and $6.6 \pm 0.09^{\circ} \mathrm{C}$, respectively).

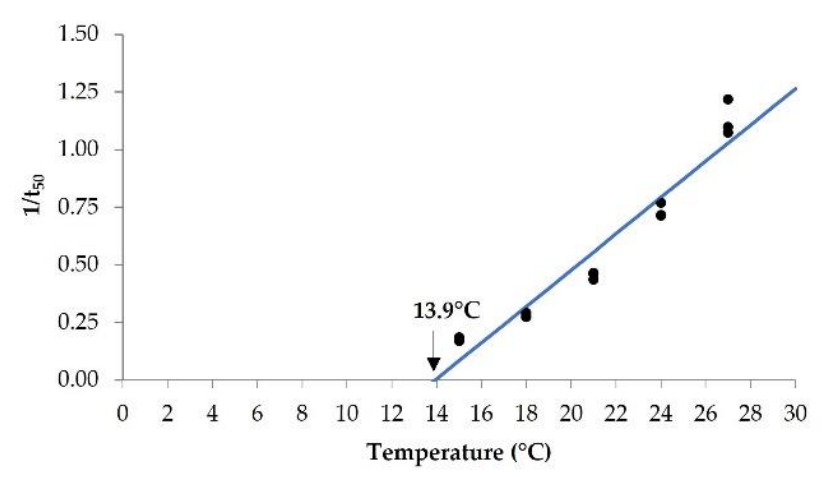

(a)

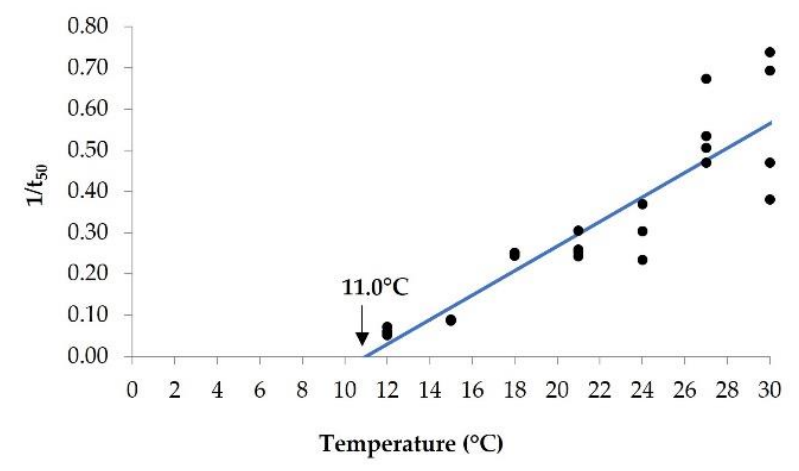

(c)

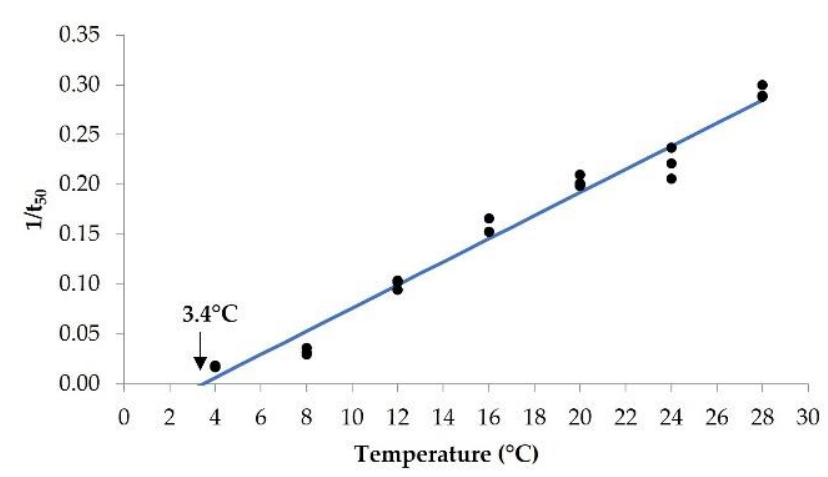

(b)

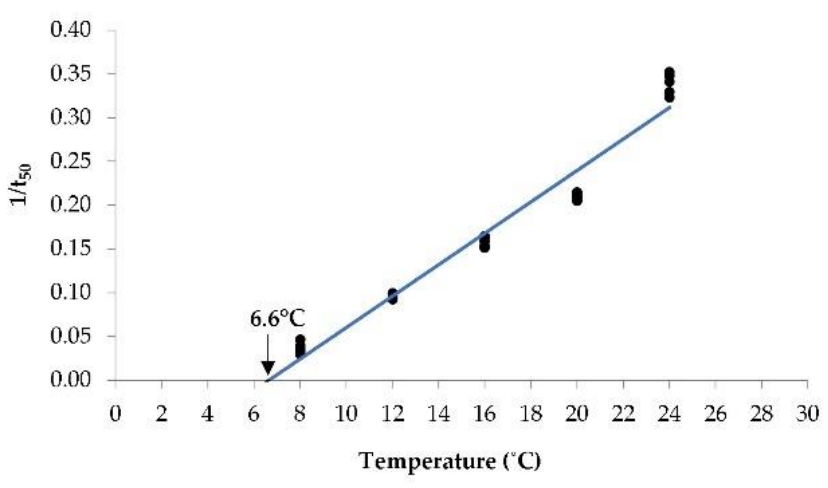

(d)

Figure 3. Estimated base temperatures. The solid line represents the linear regression line and the points represents the inverse value of the time necessary to reach $50 \%$ of germination $\left(1 / t_{50}\right)$. The estimated value of the base temperature is the intersection of the regression line with the $x$-axis: (a) Amaranthus retroflexus $\left(\mathrm{T}_{\mathrm{b}}=13.9 \pm 0.36{ }^{\circ} \mathrm{C} ; \mathrm{y}=0.079 \mathrm{x}-1.010\right.$; $\left.r^{2}=0.96\right) ;(\mathbf{b})$ Chenopodium album $\left(\mathrm{T}_{\mathrm{b}}=3.4 \pm 0.36{ }^{\circ} \mathrm{C} ; \mathrm{y}=0.012 \mathrm{x}-0.04, r^{2}=0.98\right) ;(\mathbf{c})$ Panicum capillare $\left(\mathrm{T}_{\mathrm{b}}=11.0 \pm 1.99{ }^{\circ} \mathrm{C}\right.$; $\left.\mathrm{y}=0.030 \mathrm{x}-0.328 ; r^{2}=0.82\right) ;(\mathrm{d})$ Setaria pumila $\left(\mathrm{T}_{\mathrm{b}}=6.6 \pm 0.09^{\circ} \mathrm{C} ; \mathrm{y}=0.018 \mathrm{x}-0.119 ; r^{2}=0.96\right)$. 
3.3. Germination Dynamic in Response to Different Water Potentials and Estimation of the Base Water Potential for the Tested Weed Species

The duration of the germination of all weeds varied between 0.4 and $32.3 \mathrm{~d}$, depending on the incubation water potentials and the species tested. In general, the duration of the germination increased with the decrease in water potential. The germination was extended within the abovementioned range, depending on the species (Table 2).

Table 2. Germination dynamics at different water potentials (MPa) at $22{ }^{\circ} \mathrm{C}$.

\begin{tabular}{ccccccccccccc}
\hline \multirow{2}{*}{$\mathbf{M P a}$} & \multicolumn{3}{c}{ P. capillare } & \multicolumn{3}{c}{ C. album } & \multicolumn{3}{c}{ S. pumila } & \multicolumn{3}{c}{ A. retroflexus } \\
\cline { 2 - 13 } & $\mathbf{t}_{\mathbf{1 0}}$ & $\mathbf{t}_{\mathbf{5 0}}$ & $\mathbf{t}_{\mathbf{9 0}}$ & $\mathbf{t}_{\mathbf{1 0}}$ & $\mathbf{t}_{\mathbf{5 0}}$ & $\mathbf{t}_{\mathbf{9 0}}$ & $\mathbf{t}_{\mathbf{1 0}}$ & $\mathbf{t}_{\mathbf{5 0}}$ & $\mathbf{t}_{\mathbf{9 0}}$ & $\mathbf{t}_{\mathbf{1 0}}$ & $\mathbf{t}_{\mathbf{5 0}}$ & $\mathbf{t}_{\mathbf{9 0}}$ \\
\hline $\mathbf{0 . 0 0}$ & $4.6 \mathrm{bc}$ & $5.0 \mathrm{a}$ & $5.5 \mathrm{a}$ & $2.1 \mathrm{a}$ & $3.4 \mathrm{a}$ & $5.7 \mathrm{a}$ & $2.5 \mathrm{a}$ & $3.5 \mathrm{a}$ & $4.8 \mathrm{a}$ & $1.4 \mathrm{a}$ & $1.6 \mathrm{a}$ & $1.9 \mathrm{a}$ \\
$\mathbf{- 0 . 0 5}$ & $4.7 \mathrm{bc}$ & $5.2 \mathrm{a}$ & $5.7 \mathrm{a}$ & $2.2 \mathrm{a}$ & $3.4 \mathrm{a}$ & $5.5 \mathrm{a}$ & $3.1 \mathrm{a}$ & $3.9 \mathrm{a}$ & $5.0 \mathrm{a}$ & $1.2 \mathrm{~b}$ & $1.6 \mathrm{a}$ & $2.3 \mathrm{a}$ \\
$\mathbf{- 0 . 1 0}$ & $4.6 \mathrm{bc}$ & $5.2 \mathrm{a}$ & $5.8 \mathrm{a}$ & $2.2 \mathrm{a}$ & $3.5 \mathrm{a}$ & $5.5 \mathrm{a}$ & $3.4 \mathrm{a}$ & $4.2 \mathrm{a}$ & $5.2 \mathrm{a}$ & $0.5 \mathrm{bc}$ & $1.3 \mathrm{a}$ & $3.6 \mathrm{a}$ \\
$\mathbf{- 0 . 2 5}$ & $4.0 \mathrm{ab}$ & $6.2 \mathrm{ab}$ & $10.0 \mathrm{ab}$ & $2.3 \mathrm{a}$ & $3.7 \mathrm{a}$ & $5.8 \mathrm{a}$ & $3.3 \mathrm{a}$ & $5.3 \mathrm{a}$ & $7.4 \mathrm{a}$ & $1.9 \mathrm{c}$ & $5.9 \mathrm{~b}$ & $18.6 \mathrm{~b}$ \\
$\mathbf{- 0 . 3 8}$ & $3.5 \mathrm{a}$ & $7.5 \mathrm{~b}$ & $17.9 \mathrm{~b}$ & $2.0 \mathrm{a}$ & $3.7 \mathrm{a}$ & $6.8 \mathrm{a}$ & $3.9 \mathrm{a}$ & $6.8 \mathrm{a}$ & $12.1 \mathrm{~b}$ & - & - & - \\
$-\mathbf{0 . 5 0}$ & $4.9 \mathrm{c}$ & $7.5 \mathrm{~b}$ & $12.8 \mathrm{ab}$ & $2.4 \mathrm{a}$ & $4.7 \mathrm{~b}$ & $9.1 \mathrm{a}$ & $10.1 \mathrm{~b}$ & $18.0 \mathrm{~b}$ & $32.3 \mathrm{c}$ & - & - & - \\
$\mathbf{- 0 . 8 0}$ & - & - & - & $4.5 \mathrm{c}$ & $9.6 \mathrm{~d}$ & $21.4 \mathrm{~b}$ & - & - & - & - & - & - \\
$-\mathbf{1 . 0 0}$ & - & - & - & $3.7 \mathrm{~b}$ & $8.2 \mathrm{c}$ & $18.8 \mathrm{~b}$ & - & - & - & - & - & - \\
\hline
\end{tabular}

Differences between the initial $\left(t_{10}\right)$, medium $\left(t_{50}\right)$, and final $\left(t_{90}\right)$ germination under different water potentials according to one-way analysis of variance (ANOVA). Different small letters (a-d) within a column indicate a statistical difference according to Fisher's Least Significant Difference (LSD) test at $p<0.05$.

A. retroflexus showed the highest sensitivity to water stress. After a very low germination at a water potential $<-0.25 \mathrm{MPa}$, it was not even possible to estimate the germination dynamic curve. At a water potential $>-0.25 \mathrm{MPa}$, germination lasted from 0.5 to $3.6 \mathrm{~d}$ $\left(\mathrm{t}_{10}-\mathrm{t}_{90}\right)$, and at $-0.25 \mathrm{MPa}$, germination lasted $18.6 \mathrm{~d}\left(\mathrm{t}_{90}\right)$. The other species required a longer time to reach the initial germination phase $\left(t_{10}\right)$ at a water potential $<-0.25 \mathrm{MPa}$, but then they were able to maintain similar germination dynamics until -0.38 and $-0.50 \mathrm{MPa}$ for S. pumila, C. album, and P. capillare, respectively. C. album was the only species with the ability to germinate at all investigated water potentials.

Consequently, $\Psi_{\mathrm{b}}$ was estimated with the germination dynamics shown in Table 2 and is presented in Figure 4. The lowest value was estimated for C. album $(-1.38 \pm 0.14 \mathrm{MPa})$, and the highest was estimated for $A$. retroflexus $(-0.36 \pm 0.03 \mathrm{MPa})$, while S. pumila $(-0.71 \pm 0.07 \mathrm{MPa})$ and P. capillare $(-0.86 \pm 0.07 \mathrm{MPa})$ had intermediate values.

It is important to underline that, for $P$. capillare, it was not possible to use the logistic regression model to identify the $t_{50}$ at $-0.80 \mathrm{MPa}$ due to the low germination (Figure 2). However, a value of $1 / \mathrm{t}_{50}$ close to zero was used at $-0.80 \mathrm{MPa}$ to estimate the base water potential. It was necessary to avoid underestimation of the base parameter.

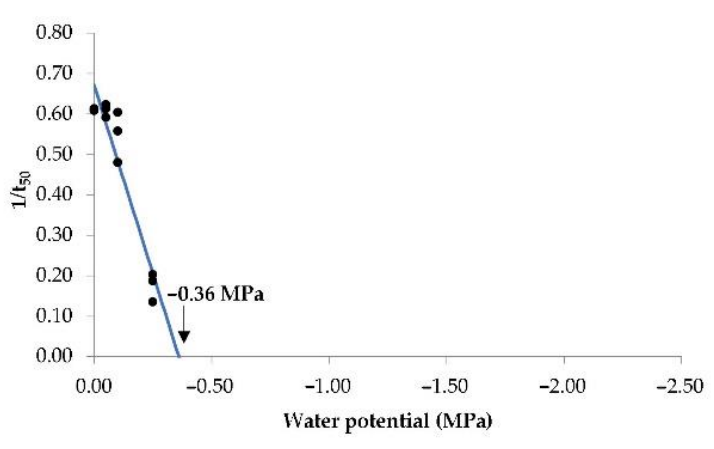

(a)

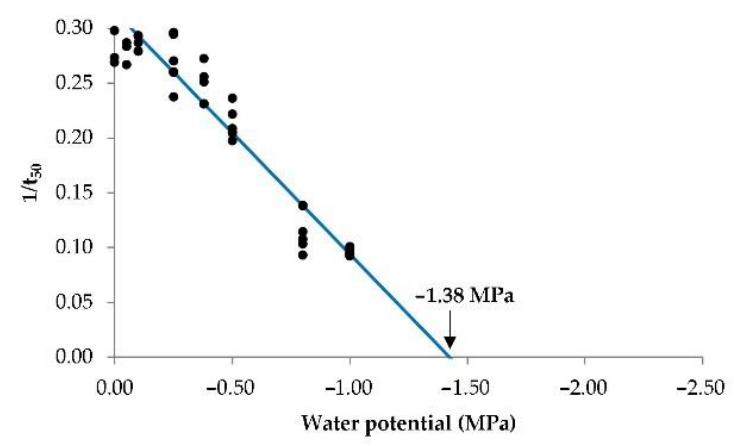

(b)

Figure 4. Cont. 


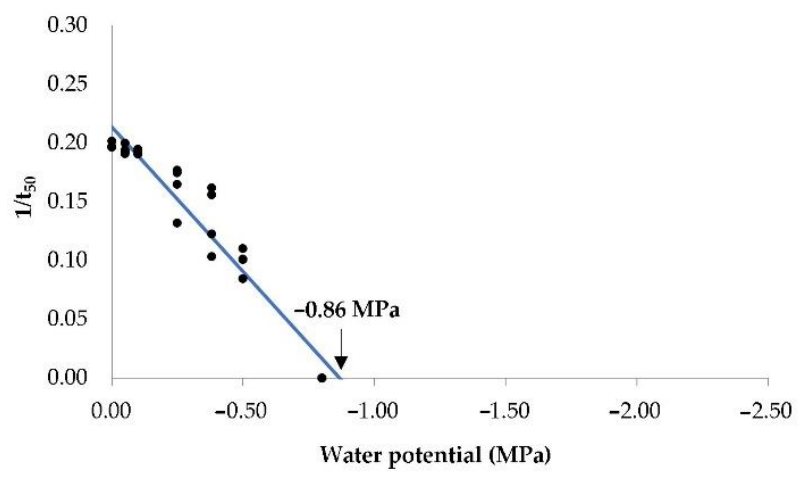

(c)

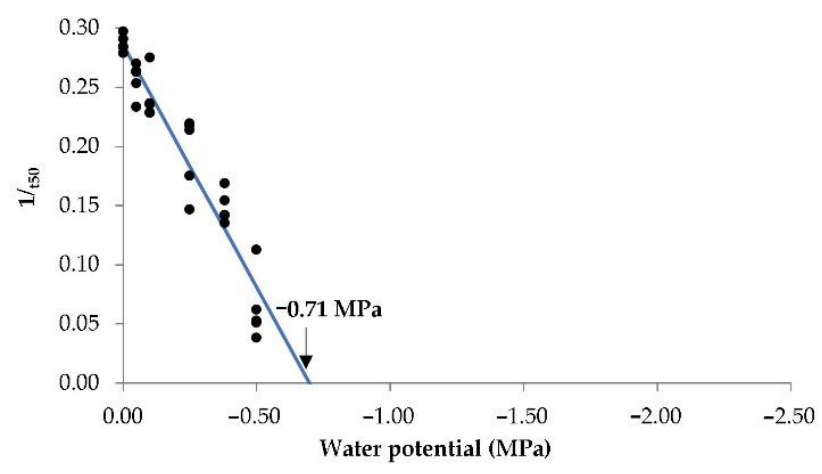

(d)

Figure 4. Estimated base water potentials $\left(\Psi_{\mathrm{b}}\right)$. The solid line represents the linear regression line, and the points represent the inverse value of the time necessary to reach $50 \%$ of germination $\left(1 / t_{50}\right)$. The estimated value of the base water potential is the intersection of the regression line with the $x$-axis: (a) Amaranthus retroflexus $\left(\Psi_{\mathrm{b}}=-0.36 \pm 0.03 \mathrm{MPa} ; \mathrm{y}=0.672 \mathrm{x}+1.862\right.$; $\left.r^{2}=0.91\right) ;(\mathbf{b})$ Chenopodium album $\left(\Psi_{\mathrm{b}}=-1.38 \pm 0.14 \mathrm{MPa} ; \mathrm{y}=0.221 \mathrm{x}+0.315 ; r^{2}=0.87\right) ;(\mathbf{c})$ Panicum capillare $\left(\Psi_{\mathrm{b}}=-0.86 \pm\right.$ $\left.0.07 \mathrm{MPa} ; \mathrm{y}=0.2466 \mathrm{x}+0.2138 ; r^{2}=0.94\right) ;$ and $(\mathbf{d})$ Setaria pumila $\left(\Psi_{\mathrm{b}}=-0.71 \pm 0.07 \mathrm{MPa} ; \mathrm{y}=0.409 \mathrm{x}+0.286 ; r^{2}=0.92\right)$.

\subsection{Comparison of the Germination Parameters of Two Populations from Different Geografical Areas}

According to the criterion of overlap of the 95\% confidence interval [1] between the Italian and Croatian populations, two out of the three species tested have similar values in an estimated parameter (Table 3). For P. capillare, it was not possible to make a comparison because the germination parameters of the Italian population of this species have not yet been estimated.

Table 3. Base temperature $\left(\mathrm{T}_{\mathrm{b}}\right)$ and base water potential $\left(\Psi_{\mathrm{b}}\right)$ of weed species for the Italian and Croatian populations, with the confidence interval (95\% CI) and coefficient of determination $\left(r^{2}\right)$. The Italian germination parameters for the three weed species (A. retroflexus, C. album, and S. pumila) were estimated by Masin et al. [1].

\begin{tabular}{|c|c|c|c|c|c|c|c|c|c|c|c|c|}
\hline \multirow{2}{*}{ Species } & \multicolumn{3}{|c|}{ Italy } & \multicolumn{3}{|c|}{ Croatia } & \multicolumn{3}{|c|}{ Italy } & \multicolumn{3}{|c|}{ Croatia } \\
\hline & $\mathrm{T}_{\mathrm{b}}\left({ }^{\circ} \mathrm{C}\right)$ & $\pm 95 \% \mathrm{CI}$ & $r^{2}$ & $\mathrm{~T}_{\mathrm{b}}\left({ }^{\circ} \mathrm{C}\right)$ & $\pm 95 \%$ CI & $r^{2}$ & $\Psi_{\mathrm{b}}(\mathrm{MPa})$ & $\pm 95 \%$ CI & $r^{2}$ & $\Psi_{\mathrm{b}}(\mathrm{MPa})$ & $\pm 95 \%$ CI & $r^{2}$ \\
\hline A. retroflexus & 12.3 & 1.12 & 0.92 & 13.9 & 0.36 & 0.96 & -0.41 & 0.07 & 0.92 & -0.36 & 0.03 & 0.95 \\
\hline C. album & 2.6 & 0.77 & 0.84 & 3.4 & 0.36 & 0.98 & -0.96 & 0.10 & 0.84 & -1.38 & 0.14 & 0.87 \\
\hline S. pumila & 10.4 & 0.95 & 0.97 & 6.59 & 0.09 & 0.96 & -0.93 & 0.11 & 0.85 & -0.71 & 0.07 & 0.92 \\
\hline P. capillare & - & - & - & 11.0 & 1.99 & 0.82 & - & - & - & -0.87 & 0.07 & 0.94 \\
\hline
\end{tabular}

The Croatian population of $A$. retroflexus had a $1.6^{\circ} \mathrm{C}$ higher base temperature compared to the Italian populations, and the overlap was not even found if the extreme of the two confidence intervals were close. Thus, these two values of $T_{b}$ can be considered as statistically different. In the Croatian population of C. album, the $\mathrm{T}_{\mathrm{b}}$ was $0.8^{\circ} \mathrm{C}$ higher than in the Italian population, but the confidence intervals overlapped. These two values are therefore not statistically different. In contrast, the $\mathrm{T}_{\mathrm{b}}$ value estimated for the Croatian population of S. pumila is $3.81{ }^{\circ} \mathrm{C}$ lower, compared to the Italian population, and it was found that they differed significantly.

The base water potential of $A$. retroflexus was $0.05 \mathrm{MPa}$ higher for the Croatian population, compared to the Italian, but no significant difference was found. A lower base water potential was determined for the Croatian population of $C$. album, and a higher base water potential was determined for S. pumila, although significant differences from the Italian population were found in both cases. Taken together, these findings indicate that similar values between Italian and Croatian populations were found only for C. album regarding $\mathrm{T}_{\mathrm{b}}$ and for $A$. retroflexus regarding $\Psi_{\mathrm{b}}$. 


\section{Discussion}

In the present study, germination parameters $\left(T_{b}\right.$ and $\left.\Psi_{b}\right)$ of four summer weed species collected in Croatia were estimated. Germination tests at different temperatures showed a species-specific preference for higher or lower temperatures. The species ranged from less to more thermophilic as follows: C. album $>$ S. pumila $>$ P. capillare $>$ A. retroflexus. This is consistent with previous studies, in which $A$. retroflexus was also found to germinate best at temperatures $>25^{\circ} \mathrm{C}$ [24] and S. pumila at temperatures of 24.5 to $34.9^{\circ} \mathrm{C}$ [25]. In the present study, $P$. capillare had the highest germination at temperatures of $18-24^{\circ} \mathrm{C}$, which is again consistent with a previous study, where P. dichotomiflorum achieved the highest germination capacity at temperatures of $25^{\circ} \mathrm{C}$ [26-29] or P. miliaceaeum at temperatures between 18 and $25^{\circ} \mathrm{C}[30,31]$. The optimal temperature for the germination of $C$. album has been reported between 15 and $25^{\circ} \mathrm{C}$ [32], which is again in line with the germination data of the present study (Figure 1).

If we compare the temperature preferences that define germination with the time of emergence in the field, as suggested in a previous study [2], the species from the present study could be divided into three categories: early (C. album), middle (S. pumila and $P$. capillare), and late emerging species (A. retroflexus). The germination dynamic data shown in this study (Table 1 ) also reflected the species-specific sensitivity to different temperatures. In particular, A. retroflexus had the shortest germination at all temperatures investigated. For example, the mean germination of this species stopped completely after 5.7 days, which is slightly faster, compared to the other studied species (Table 1). No germination was observed at and below $12^{\circ} \mathrm{C}$, confirming the thermophilic behavior of the species [2]. The $\mathrm{T}_{\mathrm{b}}$ values for $A$. retroflexus was estimated to be $13.9^{\circ} \mathrm{C}$, which is the highest $\mathrm{T}_{\mathrm{b}}$ among the species tested in the present study. This is the reason why a later emergence is observed for A. retroflexus in maize fields, compared to the other studied weeds [33]. This $\mathrm{T}_{\mathrm{b}}$ is slightly higher than the values around $12{ }^{\circ} \mathrm{C}$ reported for the Italian and Iranian populations [1,11], and even lower values, i.e., 10.5 and $8.9^{\circ} \mathrm{C}$, have been reported for other populations from Germany and France, respectively $[19,34]$. In contrast, our study estimated that the $\mathrm{T}_{\mathrm{b}}$ for C. album is $3.4{ }^{\circ} \mathrm{C}$, making it the species with the lowest temperature requirement, thus confirming its early germination behavior [2]. This value is similar to the $T_{b}$ reported for Italian and Dutch populations [1,35], while a significantly higher value was reported for a French population [19]. The value of $\mathrm{T}_{\mathrm{b}}\left(6.6^{\circ} \mathrm{C}\right)$ estimated for the Croatian population of S. pumila is lower than the range of values $\left(8.6-10.4^{\circ} \mathrm{C}\right)$ reported in previous studies on populations from Italy, France, and California $[1,19,30]$. In our study, we also estimated the $\mathrm{T}_{\mathrm{b}}$ for P. capillare, and as far as we know, this is the first report globally on the base temperature for this weed species. We found that $11{ }^{\circ} \mathrm{C}$ is the base temperature for $P$. capillare. Our results are consistent with another study, in which the minimum temperature for the germination of P. miliaceaum was also estimated to be $11^{\circ} \mathrm{C}$ [31].

Since temperature was not the only factor found to trigger germination in the present study, we also observed the germination capacity of the same weed species under different water potentials. Depending on their water requirements, the species in this study ranged from less to more tolerant as follows: A. retroflexus $\left(\Psi_{\mathrm{b}}-0.36 \mathrm{MPa}\right)<$ S. pumila $\left(\Psi_{\mathrm{b}}-0.71 \mathrm{MPa}\right)<$ P. capillare $\left(\Psi_{\mathrm{b}}-0.86 \mathrm{MPa}\right)<$ C. album $\left(\Psi_{\mathrm{b}}-1.38 \mathrm{MPa}\right)$ (Figure 4$)$. In addition to the study performed to calibrate the AlertInf model [1], only a single study conducted in France has determined the $\Psi_{\mathrm{b}}$ for these species [19]. The value of $\Psi_{\mathrm{b}}$ estimated for the Croatian population of A. retroflexus is similar to the $\Psi_{\mathrm{b}}$ used in AlertInf for a population from Northern Italy, while lower values were reported for other populations from Central Italy $(-0.62 \mathrm{MPa})$ and France $(-0.95 \mathrm{MPa})[1,19]$. Regarding the $\Psi_{\mathrm{b}}$ for S. pumila, an almost identical value was described for a French population $(-0.75 \mathrm{vs}$. $-0.71 \mathrm{MPa}$ ), while a lower value was determined for the Italian population included in AlertInf $[1,19]$. Finally, the Croatian population of C. album had a lower $\Psi_{\mathrm{b}}$ in comparison with the values previously reported for both Italian $(-0.96$ and $-1.04 \mathrm{MPa})$ and French $(-0.80 \mathrm{MPa})$ populations $[1,19]$. As far as we know, there are no data of $\Psi_{\mathrm{b}}$ for the species $P$. capillare, in the literature. The germination behavior of the investigated species at different 
temperature and water potential regimes shows that the species with a better tolerance to lower temperatures also had a better tolerance to a lower water potential.

The main objective of the present study was to compare the estimated values of germination parameters for C. album, S. pumila, and A. retroflexus seeds collected at different geographical locations in order to verify the possibility of using the hydrothermal model, AlertInf, in different geographical locations. We wanted to examine if the $T_{b}$ and $\Psi_{b}$ values estimated in this study would be comparable with those estimated in Alertinf [4], as a first step of transferring the weed predictive model, AlertInf, out of its original geographical region. Two out of the three Croatian species had a parameter overlapping with the Italian population: C. album had a similar $\mathrm{T}_{\mathrm{b}}$ but a different $\Psi_{\mathrm{b}}$, A. retroflexus had a different $\mathrm{T}_{\mathrm{b}}$ but a similar $\Psi_{b}$, and $S$. pumila differed in both germination parameters (Table 3).

The present study therefore showed that a similar germination of Croatian and Italian populations may only be expected for C. album, since the $\mathrm{T}_{\mathrm{b}}$ value was similar. However, this is valid only in conditions where soil water is not limited, since the $\Psi_{b}$ differed significantly between the two populations. The next step will therefore be to evaluate the weed emergence patterns of C. album in irrigated maize fields and then try to calibrate the AlerInf equation parameters. The prediction of A. retroflexus and S. pumila using the AltertInf model with its original parameters is unfortunately impossible, even in irrigated maize crops, since the $\mathrm{T}_{\mathrm{b}}$ values of Croatian populations differ statistically from those of the Italian populations present in the hydrothermal model. This variability in germination parameters has also been documented in previous studies and is usually explained as an adaptation process of weed species to local climate conditions [13,36]. The annual air temperature in Zagreb is, on average, lower than that in Padova. Moreover, comparing the temperatures in spring (March-June) and summer (July-October) in Zagreb $\left(6.4-19.4{ }^{\circ} \mathrm{C} ; 21.1-11.0{ }^{\circ} \mathrm{C}\right)$ and Padova $\left(9.0-22.0{ }^{\circ} \mathrm{C} ; 23.1-14.0{ }^{\circ} \mathrm{C}\right)$ during a thirty-year period, it is evident that Zagreb has lower air temperatures. Therefore, we expected that the populations in Zagreb and the surrounding area would have lower $\mathrm{T}_{\mathrm{b}}$ values, compared to those in Padova, as suggested earlier [1,12]. This was found to be case for S. pumila and C. album; however, this phenomenon was not found for A. retroflexus, where the $\mathrm{T}_{\mathrm{b}}$ was found to be higher for the Croatian (colder climate) than for the Italian population (warmer climate). Unfortunately, the complexity of weed seed biology, especially in the period of seed ripening, can influence the germination behavior of seeds. The involvement of various factors that determine the characteristics of the seed (position on the mother plant, micro-environmental conditions, availability of nutrients, etc.) can cause differences in dormancy and germination requirements [37,38]. An attempt to implement the model in another agro-ecological area was also made by Bürger and Colbach [15] using the FlorSys model. The difference in base temperature for different species was also species-specific, and it was not possible to find a pattern connected to climate conditions. They found a 4.3 lower $\mathrm{T}_{\mathrm{b}}$ for $\mathrm{C}$. album, and a $4.0^{\circ} \mathrm{C}$ higher $\mathrm{T}_{\mathrm{b}}$ for E. crus-galli in Germany, compared to France.

\section{Conclusions}

C. album, A. retroflexus, S. pumila, and P. capillare are highly distributed weed species globally [39] and in Croatian maize fields [40]. The present study offers a way to implement the predictive emergence model, AlertInf, for C. album in a non-irrigated field.

However, further field trials are necessary and should be carried out in two directions depending on the weed species. First, for C. album or A. therophrasti, due to their estimated $\mathrm{T}_{\mathrm{b}}$ overlap with the Italian populations [16], AlertInf needs to be further validated by comparing the emergence of the species in maize fields with those predicted by AlertInf. Second, the model should be adjusted for the species S. pumila and A. retroflexus, as the germination parameters differ significantly. Third, AlertInf should be extended to $P$. capillare, whose germination parameters have now been estimated for the first time. Furthermore, the results of this study highlight the importance of the need to develop and adapt a predictive weed emergence model for a specific agro-ecological area. With a 
few exceptions [11], the comparison made in this study andin some other studies [1,11,15] showed that emergence models cannot be applied globally, and it is important to establish a dataset with local weed germination parameters to introduce the emergence model into a new area. However, the results are valuable as they provide estimated biological germination parameters for four species that have never been estimated before in Croatia. This is the first and obligatory step towards the development/transfer of a model to predict their emergence

Author Contributions: Conceptualization, V.Š., M.Š., and R.M.; methodology, R.M. and D.L.; software, R.M.; validation, all authors; formal analysis R.M. and V.Š.; investigation, V.Š. and E.B.; resources, R.M., D.L., and M.Š.; data curation, V.Š. and E.B.; writing-original draft preparation, V.Š. and M.S..; writing—review and editing, all authors; visualization, V.Š.; supervision, M.Š. and R.M.; project administration, M.Š.; funding acquisition, R.M. and M.Š. All authors have read and agreed to the published version of the manuscript.

Funding: This research received no external funding.

Institutional Review Board Statement: Not applicable.

Informed Consent Statement: Not applicable.

Data Availability Statement: All relevant data for this study are reported in this article.

Acknowledgments: Publication was supported by the Open Access Publication Fund of the University of Zagreb Faculty of Agriculture.

Conflicts of Interest: The authors declare no conflict of interest.

\section{References}

1. Masin, R.; Loddo, D.; Benvenuti, S.; Zuin, M.C.; Macchia, M.; Zanin, G. Temperature and water potential as parameters for modeling weed emergence in central-northern Italy. Weed Sci. 2010, 58, 216-222. [CrossRef]

2. Werle, R.; Sandell, L.D.; Buhler, D.D.; Hartzler, R.G.; Lindquist, J.L. Predicting emergence of 23 summer annual weed species. Weed Sci. 2014, 62, 267-279. [CrossRef]

3. Forcella, F.; Benech Arnold, R.L.; Sanchez, R.; Ghersa, C.M. Modelling seedling emergence. Field Crops Res. 2000, 67, 123-139. [CrossRef]

4. Masin, R.; Loddo, D.; Benvenuti, S.; Otto, S.; Zanin, G. Modeling weed emergence in Italian maize fields. Weed Sci. 2012, 60, 254-259. [CrossRef]

5. Dorado, J.; Sousa, E.; Cahla, I.M.; González-Andújar, J.M.; Fernández-Quintanilla, C. Predicting weed emergence in maize crops under two contrasting climatic conditions. Weed Res. 2009, 49, 251-260. [CrossRef]

6. Masin, R.; Loddo, D.; Gasparini, V.; Otto, S.; Zanin, G. Evaluation of weed emergence model AlertInf for maize in soybean. Weed Sci. 2014, 62, 360-369. [CrossRef]

7. Royo-Esnal, A.; García, A.L.; Torra, J.; Forcella, F.; Recasens, J. Describing Polygonum aviculare emergence in different tillage systems. Weed Res. 2015, 55, 387-395. [CrossRef]

8. Izquierdo, J.; Bastida, F.; Lezaún, J.M.; Sánchez del Arco, M.J.; González-Andújar, J.L. Development and evaluation of a model for predicting Lolium rigidum emergence in winter cereal crops in the Mediterranean area. Weed Res. 2013, 53, 269-278. [CrossRef]

9. Bradford, K.J. Applications of hydrothermal time to quantifying and modeling seed germination and dormancy. Weed Sci. 2002, 50, 248-260. [CrossRef]

10. Leguizamon, E.S.; Fernandez-Quintanilla, C.; Barroso, J.; Gonzalez-Andujiar, J.L. Using thermal and hydrothermal time to model seedling emergence of Avena sterilis ssp. ludoviciana in Spain. Weed Res. 2005, 45, 149-156. [CrossRef]

11. Loddo, D.; Ghaderi-Far, F.; Rastegar, Z.; Masin, R. Base temperatures for germination of selected weed species in Iran. Plant Prot. Sci. 2018, 54, 60-66.

12. CBS-Croatian Bureau of Statistics. Available online: https://www.dzs.hr/default_e.htm (accessed on 15 November 2020).

13. Loddo, D.; Sousa, E.; Masin, R.; Calha, I.; Zanin, G.; Fernández-Quintanilla, C.; Dorado, J. Estimation and Comparison of Base Temperatures for Germination of European Populations of Velvetleaf (Abutilon theophrasti) and Jimsonweed (Datura stramonium). Weed Sci. 2013, 61, 443-451. [CrossRef]

14. Leiblein-Wild, M.C.; Kaviani, R.; Tackenberg, O. Germination and seedling frost tolerance differ between the native and invasive range in common ragweed. Oecologia 2014, 174, 739-750. [CrossRef] [PubMed]

15. Bürger, J.; Colbach, N. Germination base temperature and relative growth rate of 13 weed species-Comparing populations from two geographical origins. In Proceedings of the 28th German Conference on Weed Biology and Weed Control, Braunschweig, Germany, 27 February-1 March 2018; Volume 458, pp. 419-426. 
16. Šoštarčić, V.; Šćepanović, M.; Masin, R.; Magosso, D.; Zanin, G. Estimation of biological parameters for germination of Abutilon theophrasti Medik. Period. Biol. 2018, 120, 81-89. [CrossRef]

17. Kottek, M.; Grieser, J.; Beck, C.; Rudolf, B.; Rubel, F. World map of the Koppen-Geiger climate classificationupdated. Meteorol. Z. 2006, 15, 259-263. [CrossRef]

18. Steinmaus, S.J.; Prather, T.S.; Holt, J.S. Estimation of base temperatures for nine weed species. J. Exp. Bot. 2005, 1, 275-286. [CrossRef]

19. Guillemin, J.P.; Gardarin, A.; Granger, S.; Reibel, C.; Munier-Jolain, N.; Colbach, N. Assessing potential germination period of weeds with base temperatures and base water potentials. Weed Res. 2013, 53, 76-87. [CrossRef]

20. Masin, R.; Zuin, M.C.; Archer, D.W.; Zanin, G. WeedTurf: A predictive model to aid control of annual summer weeds in turf. Weed Sci. 2005, 53, 193-201. [CrossRef]

21. Michel, B.E.; Kaufmann, M.R. The Osmotic Potential of Polyethylene Glycol 6000. Plant Physiol. 1973, 51, 914-916. [CrossRef]

22. Onofri, A. Bioassay97: A new Excel VBA macro to perform statistical analyses on herbicide dose-response data. Ital. J. Agrometeorol. 2001, 3, 40-45.

23. Efron, B. Bootstrap methods: Another look at the jackknife. Ann. Stat. 1979, 7, 1-26. [CrossRef]

24. Steckel, E.L.; Sprague, C.L.; Stoller, E.W.; Wax, L.M. Temperature Effects on Germination of Nine Amaranthus Species. Weed Sci. 2004, 52, 217-221. [CrossRef]

25. Mollaee, M.; Darbandi, E.I.; Aval, M.B.; Chauhan, B.S. Germination response of three Setaria species (S. viridis, S. verticillata, and S. glauca) to water potential and temperature using non-linear regression and hydrothermal time models. Acta Physiol. Plant 2020, 42, 149. [CrossRef]

26. Rivera, C.M.; Peters, R.A. A preliminary report on formation of seed and germination of fall panicum (Panicum dichotomiflorum Michx.) and witchgrass (P. capillare L.). Proc. NEWCC 1971, 25, 30.

27. Vengris, J.; Damon, R.A. Field growth of fall panicum and witchgrass. Weed Sci. 1976, 24, 205-208. [CrossRef]

28. Baskin, J.M.; Baskin, C.C. Seasonal changes in the germination responses of buried witchgrass (Panicum capillare) seeds. Weed Sci. 1986, 34, 22-24. [CrossRef]

29. Smith, A.A. The Effects of Seed Mass and Emergence Order on Growth and Reproduction of Fall Panicum (Panicum dichotomiflorum Michx.). Master's Thesis, The Ohio State University, Columbus, OH, USA, 1986.

30. Kalinová, J.; Moudrý, J. Frost resistance evaluation of the common millet (Panicum miliaceum L.) varieties. Agricultura 2005, 3, 10-12.

31. James, T.K.; Rahman, A.; Mcgill, C.R.; Trivedi, P.D. Biology and survival of broom corn millet (Panicum miliaceum) seed. N. Z. Plant Prot. 2011, 64, 142-148. [CrossRef]

32. Altenhofen, L.M. The Effects of Light, Temperature, After-Ripening, Nitrate and Water on Chenopodium album Seed Germination. Master's Thesis, Iowa State University, Ames, IA, USA, 2009.

33. Myers, M.W.; Curran, W.S.; VanGessel, M.J.; Calvin, D.D.; Mortensen, D.A.; Majek, B.A.; Karsten, H.D.; Roth, G.W. Predicting weed emergence for eight annual species in the northeastern United States. Weed Sci. 2004, 52, 913-919. [CrossRef]

34. Bürger, J.; Malyshev, A.V.; Colbach, N. Populations of arable weed species show intraspecific variability in germination base temperature but not in early growth rate. PLoS ONE 2020, 15, e0240538. [CrossRef] [PubMed]

35. Vleeshouwers, L.M.; Kropff, M.J. Modelling field emergence patterns in arable weeds. New Phytol. 2000, 148, 445-457. [CrossRef]

36. Loddo, D.; Bozic, D.; Calha, I.M.; Dorado, J.; Izquierdo, J.; Šćepanović, M.; Barić, K.; Carlesi, S.; Leskovsek, R.; Peterson, D.; et al. Variability in seedling emergence for European and North American populations of Abutilon theophrasti. Weed Res. 2019, 59, 15-27. [CrossRef]

37. Fenner, M. The effects of the parent environment on seed germinability. Seed Sci. Res. 1991, 1, 75-84. [CrossRef]

38. Baskin, C.C.; Baskin, J.M. Seed Ecology, Biogeography, and Evolution of Dormancy and Germination; School of Biological Sciences, University of Kentucky: Lexington, KY, USA; Academic Press: Cambridge, MA, USA, 2001; pp. 181-219.

39. Holm, L.; Doll, J.; Holm, E.; Pancho, J.; Herberger, J. World Weeds: Natural Histories and Distribution; Wiley: New York, NY, USA, 1997.

40. Šarić, T.; Ostojić, Z.; Stefanović, L.; Deneva Milanova, S.; Kazinczi, G.; Tyšer, L. The changes of the composition of weed flora in southeastern and central europe as affected by cropping practices. Herbologia 2011, 12, 8-12. 